УДК 811.161.2

\title{
ДИСКУРСИВНІ ПРАКТИКИ В МІЖКУЛЬТУРНІЙ КОМУНІКАЦІЇ
}

\author{
Діброва Валентина Анатоліївна \\ кандидат філологічних наук, \\ Київський національний університет культури і мистецтв, \\ м. Київ, Україна \\ ORCID: 0000-0002-4542-0098 \\ valuscha1982@ukr.net

\section{Лікарчук Дар'я Сергіївна} \\ кандидат політичних наук, \\ Київський національний університет культури і мистецтв, \\ м. Київ, Україна \\ ORCID: 0000-0003-1603-7601 \\ likarchukd@gmail.com
}

Надіслано:

01.03.2019 Рецензовано: 15.03.2019 Прийнято: 29.03.2019

Стаття присвячена вивченню дискурсивних практик заперечення в міжкультурній комунікації як різновид дискурсивної соціальної практики. Багатосторонній характер міжкультурної комунікації визначає комплексність проблем вивчення міжкультурного спілкування з точки зору культурології, лінгвістики, соціології, філософії, етнології, прагматики, теорії масової комунікації, політології та державного управління. Дослідження прагматичного аспекту міжкультурної комунікації $є$ актуальним з точки зору комплексного підходу, що сприяє виявленню картини світу народу, його способу життя, а соціокультурна обумовленість мови дозволяє встановити факти культури народу, що в міжкультурному діалозі сприяє кращому взаєморозумінню. У статті зазначено, що $є$ істотна відмінність між соціокультурним простором та часом й мультикультурним простором.

3 нашої точки зору, сучасна ситуація вимагає розробки нових стратегій міжкультурних комунікацій, орієнтованих на активізацію не лише національно-культурних потенціалів суспільства, але й ментальних, духовних внутрішньо особистісних ресурсів кожної людини.

Ключові слова: комунікація; міжкультурна комунікація; парламентські дебати; лінгвістика; мультикультурний простір; міжнародні відносини. 
DibrovaValentyna, Candidate of Philological Sciences, Kyiv National University of Culture and Arts, Kyiv, Ukraine;

Likarchuk Dariina, Candidate of Political Sciences, Kyiv National University of Culture and Arts, Kyiv, Ukraine

\section{Discussion practices of interview in intercultural communication}

The article is devoted to the study of discursive practices of denial in intercultural communication as a kind of discursive social practice. The multidimensional nature of intercultural communication determines the complexity of the problems of studying intercultural communication from the point of view of culture studies, linguistics, sociology, philosophy, ethnology, pragmatics, the theory of mass communication, political science and public administration. The study of the pragmatic aspect of intercultural communication is relevant from the point of view of the integrated approach that helps to reveal the picture of the world of the people, its way of life, and the socio-cultural conditionality of the language allows us to establish the facts of the culture of the people, which contributes to better mutual understanding in the intercultural dialogue. The article noted that there is a significant difference between sociocultural space and time and multicultural space.

From our point of view, the current situation of the development of new strategies of cultural communities that are active in activism is not deprived of the national and cultural potential of the society, a lot of mental and spiritual growth, and there is no new pattern of new growth.

Key words: communication;intercultural communication; parliamentary debates; linguistics; multicultural space;international relations.

Диброва Валентина Анатольевна, кандидат филологических наук, Киевский национальный университет культуры и искусств, г. Киев, Украина;

Ликарчук Дарья Сергеевна, кандидат политических наук, Киевский национальный университет культуры и искусств, г. Киев, Украина

Дискурсивные практики в межкультурной коммуникации

Статья посвящена изучению дискурсивных практик межкультурной коммуникации как разновидность дискурсивной социальной практики. Многосторонний характер межкультурной коммуникации определяет комплексность проблем изучения межкультурного общения с точки зрения культурологии, лингвистики, социологии, философии, этнологии, прагматики, теории массовой коммуникации, политологии и государственного управления. Исследование прагматического аспекта межкультурной коммуникации является актуальным с точки зрения комплексного подхода, способствует выявлению картины мира народа, его образа жизни, а социокультурная обусловленность языка позволяет установить факты культуры народа, в межкультурном диалоге способствует лучшему взаимопониманию. В статье 
отмечено, что есть существенное различие между социокультурным пространством и временем и мультикультурным пространством.

C нашей точки зрения, современная ситуация требует разработки новых стратегий межкультурных коммуникаций, ориентированных на активизацию не только национально-культурных потенциалов общества, но и ментальных, духовных внутренне личностных ресурсов каждого человека.

ключевые слова: коммуникация; межкультурная коммуникация; парламентские дебаты; лингвистика; мультикультурное пространство; международные отношения.

\section{Вступ}

Сьогодні політична, соціальна, економічна науки характеризуються посиленням уваги до ролі людського фактора в мові, що $є$ визначальним критерієм для досліджень, спрямованих на комплексне вивчення мовного спілкування. Очевидно, що вивчати тільки мовну сторону даного питання недостатньо, необхідно враховувати й ситуативні, культурні фактори та сучасні аспекти комунікації.

\section{Аналіз останніх досліджень і публікацій}

Проблема виокремлення мови як основного елемента комунікації, ведення парламентських дебатів, переговорів й дослідження впливу на формування культурної ідентичності та культурного горизонту було розглянуто такими дослідниками, як: П. Бергером, К. Гергеном, Ж. Дерріда, Т. Лукманом, Дж. Фіске.

Необхідність міжкультурних комунікацій в сучасному суспільстві їх специфіку та функції розглядають такі українські вчені. як: Л. Амикін, П. Вівчарський, В. Дібров, С. Дубовик, Д. Лікарчук, А. Новак, Г. Шишкевич.

\section{Виділення невирішених раніше частин загальної проблеми}

Актуальність теми даного дослідження, обумовлено необхідністю пошуку нових способів взаємодії з представниками як власної, так й інших культур в ситуаціях політичної нестійкості, широким використанням недосконалих моделей взаємодії носіїв різних культурних стандартів. Людство досягло розуміння необхідності вироблення і застосування нових принципів стратегії й тактики міжкультурної взаємодії. Сучасна ситуація вимагає розробки нових стратегій міжкультурних комунікацій, орієнтованих на активізацію не лише національно-культурних потенціалів суспільства, але й ментальних, духовних внутрішньо особистісних ресурсів кожної людини.

\section{Формулювання цілей статті}

Метою статті $\epsilon$ аналіз дискурсивних практик заперечення в міжкультурній комунікації. 


\section{Виклад основного матеріалу дослідження}

Особливе значення для даного дослідження є концепція М.Халлера, який в своїх роботах запропонував моделі та принципи реалізації повсякденних культурних дискурсів як механізму адаптації до життєвих ситуацій та класифікацію імперативів поведінки людини в типових культурних ситуаціях (Haller, 2002, p. 152).

На жаль, в наявних дослідженнях вітчизняних й зарубіжних авторів не досить повно розкрито сам механізм міжкультурних комунікацій, а саме не розглянуті процеси розширення культурного горизонту, формування оцінки нових культурних реалій й адаптації в рамках мультикультурного простору, а також не вивчені моделі міжкультурної комунікації.

Мультикультурний простір як сфера актуалізації міжкультурної взаємодії та комунікативний простір залишаються найменше дослідженими. Теоретичний та емпіричний аналіз дискурсивної практики особистості в міжкультурних комунікаціях, «долучення» особистості в динаміку міжкультурних комунікацій за допомогою дискурсивної практики у науці знаходиться тільки в стадії позначення актуальності свого існування.

Міжкультурна комунікація $\epsilon$ не тільки безпосередньою розмовою представників різних культур і етносів. У процесі міжкультурного контакту відбувається діалог й взаємодія культур за допомогою обміну культурною інформацією між партнерами з комунікації (Steinmetz, 2001, p. 141). Наукове осмислення діалогу й взаємодії культур $\epsilon$ актуальним 3 точки зору прагматичного аспекту міжкультурної комунікації.

Сучасний стан міжкультурних взаємин характеризується, з одного боку, інтенсифікацією процесів взаємодії різних культур, 3 іншого боку диференційованістю та пошуком культурної ідентичності. Процес глобалізації проявляється все більше в активізації культурних міжнародних зв'язків.

У той же час, незважаючи на процеси уніфікації культур, спостерігається різноманіття культурного оформлення світу, яке впливає на міжкультурні контакти. Виходячи 3 аналізу різних видів комунікацій в культурі, Б. Вейденфелз зауважив, що: «Визнання факту існування культурного різноманіття, значущих відмінностей між культурами різних народів, історичних епох, цивілізацій $€$ необхідним компаративним аналізом даної проблеми» (Waidenfels, 2000, p. 247).

Як вже зазначалося, саме багатосторонній характер міжкультурної комунікації визначає комплексність проблем вивчення міжкультурного спілкування з точки зору культурології, лінгвістики, соціології, філософії, етнології, прагматики, теорії масової комунікації, політології та державного управління. Дослідження прагматичного аспекту міжкультурної комунікації $\epsilon$ актуальним з точки зору комплексного підходу, що сприяє виявленню картини 
світу народу, його способу життя, а соціокультурна обумовленість мови дозволяє встановити факти культури народу, що в міжкультурному діалозі сприяє кращому взаєморозумінню (Giles, Middleton, 1999, p. 52). В умовах глобалізації та тенденцій до інтеграції культур вивчення прагматичного аспекту міжкультурної комунікації сприяє розширенню поля міжкультурної взаємодії.

У даному аспекті варто зазначити, що мовна комунікація - це стратегічний процес, і основою для його існування є вибір оптимальних мовних ресурсів (Dibrova, 2019, p. 228). Міжособистісна інтеракція побудована на реалізації учасниками комунікації через стратегії, тактики, комунікативні технології та механізми, що забезпечують успішність взаємодії. Як показало проведене дослідження, вивчення комунікативних тактик та стратегій представляє великий інтерес на сучасному етапі розвитку політології та лінгвістики.

Зростаючий інтерес до механізмів, що є основою взаємодії партнерів у переговорах, дебатах, забезпечує ефективність комунікації, - досягнення поставлених комунікативних цілей.

Специфіка моделей міжкультурних комунікацій виражається в наступних положеннях:

- моделі підвищують якість та ефективність культурного горизонту, налагоджують зв'язки в самоорганізації, саморегуляції та відповідності мовного (вербального) впливу в комунікації;

- моделі міжкультурної комунікації в умовах культурної нестійкості є, по своїй суті, моделями розширення культурного горизонту й включають в себе моделі формування нормативної зрілості, моделі розвитку навичок «Scriptwriter», моделі формування та розвитку «WE-IMAGE», культурної ідентичності, моделі розвитку комунікативних навичок для реалізації дискурсивної практики в умовах невизначеної культурної ситуації;

- моделі міжкультурних комунікацій спираються на дискурсивну практику, пов'язану з формуванням плану й актуалізацією прототипів, схем, нормативного тексту як форм конденсації, зберігання й передачі інформації, та контроль з боку інститутів соціалізації;

- моделі є результатом впливу інститутів соціалізації на суб'єктів міжкультурних комунікацій в процесі дискурсивної практики, тому $\epsilon$ можливість підвищення рівня їх самоорганізації та оволодіння комунікативними навичками і культурно-інтегративними уміннями;

- моделі освоєння навичок й умінь $є$ алгоритмом, що представляє собою сім основних елементів: виокремлення труднощів, причин, засобів, ресурсів, пошук функціональних одиниць, визначення мети й пошук необхідної інформації. 
- при реалізації моделей міжкультурних комунікацій необхідно враховувати основні проблеми, що пов'язані 3 формуванням й розвитком нормативної зрілості, культурної ідентичності, навичок дискурсивної практики в комунікації;

- вищевказані моделі можуть бути застосовані не на рівні культури в цілому, а на рівні носіїв культури, організованих в групу й, що вже знаходяться в ситуації монокультурної діалогічної взаємодії. Ефективність моделей буде багато в чому залежати від якості відносин всередині групи та культурного досвіду кожного з представників групи. Причому культурний досвід залежить від ступеня сформованості культурно-інтеграційних умінь й комунікативних навичок. Організація носіїв культури в групі не може бути розглянута тільки як процес уніфікації культурного досвіду кожного з її представників;

- для реалізації зазначених моделей необхідно дати не тільки характеристику кожного рівня культурного горизонту, який передбачає наявність певних умінь і навичок, а й описати набір необхідних тактик, орієнтованих на розвиток й формування умінь та навичок, що дозволяють індивіду досягти наступного, більш високого рівня культурного горизонту;

- в результаті засвоєння знань, умінь та навичок міжкультурної комунікації в процесі виконання задач при переході від одного рівня культурного горизонту до іншого з'являються якісно нові особливості комунікації: від навичок орієнтації в нормативному середовищі; від толерантності до представників іншої культури, до готовності зміни особистісно значущих стандартів; дотримання соціальних норм; від появи здатності використовувати альтернативні схеми мислення й оцінювання, до розвиненої здатності здійснювати вибір адекватної моделі поведінки (Haller, 2002, p. 141).

Аналіз в рамках зазначених моделей дозволив нам виявити сутність досліджуваного комунікативного прийому під час парламентських дебатів, врегулювання та вирішення конфліктів, ведення переговорів (Likarchuk, 2014, p.359). У рамках даного дослідження варто зазначити, що сама семантика поняття заперечення $\epsilon$ досить складною парадигмою, тому зміст комунікативного підходу заперечення грунтується на декількох значеннях, серед яких виокремлюються значення незгоди, заперечення й протиставлення.

Об'єктивні причини визначають безпосередньо саме існування індивідів в мультикультурному просторі й реалізуються тільки у вигляді мовної діяльності людини. Суб'єктивна «підстава» міжкультурних комунікацій визначає власну позицію особистості в мультикультурному просторі, завдяки найбільш ефективному способу ми досягли поліпшення якості міжкультурних комунікацій - розвиток здібностей організації особистого культурного досвіду й розширення безпосередньо культурного горизонту. 


\section{Діброва Валентина Анатоліївна, Лікарчук Дар'я Сергіївна \\ Дискурсивні практики \\ в міжкультурній комунікації}

Контекстуальність та поліфонічність культурних явищ, наявність об'ємного поля існування різних соціальних норм й сценаріїв поведінки вимагають від учасників міжкультурного спілкування наступних здібностей в організації особистого культурного досвіду:

- готовність до пошуку рішення, незалежних від тієї чи іншої встановленої норми;

- готовність до створення й засвоєння нових норм, ніж прив'язаність до застарілих комунікативних норм;

- максимальний ступінь контролю у відношенні до своїх дій;

- особиста автономія у виборі того чи іншого типу поведінки (Steinmetz, 2001, p. 121).

\section{Висновки}

Виявлення основних методологічних й теоретичних основ дослідження міжкультурних комунікацій, а також аналіз практичної сторони взаємодії представників різних культур дозволяють нам дати систематичний огляд підсумків виконаної роботи і їі основних теоретичних та світоглядних висновків.

Перший висновок, який дозволив нам сформулювати власне бачення міжкультурних комунікацій в сучасному світі, пов'язаний з розглядом деяких теоретичних концепцій, моделей пізнання міжкультурних комунікацій i, насамперед, трьох довколишніх феноменів - спілкування, соціальної інформації та комунікації.

Ми не виявили різкого розмежування між класичними теоріями розвитку та некласичними теоріями зміни щодо осмислення специфіки, функцій і змісту комунікаційних процесів між представниками різних культур. Переважно як в традиційних раціоналістичних концепціях, так i в постмодерністському ірраціоналізмі сам феномен міжкультурних комунікацій дуже мало вивчений. Розглянуті нами моделі є моделі пізнання спілкування, соціальної інформації та соціальної комунікації й орієнтовані на вивчення соціокультурного простору й часу життєдіяльності людей як поля, в якому тривалий час діють певні соціокультурні стандарти, спостерігаються відносно постійні або циклічно повторювані явища. Взаємодія ж представників різних культур позбавлена цілісності, єдності, вона характеризується проявом «тільки тут і зараз», що вказує на існування певного поля, яке передбачає умовність дії старих культурних стандартів.

Основною невірною думкою всіх теорій спілкування, інформації та комунікацій є те, що поле, яке характеризує ситуацію зіткнення культур, і поле взаємодії представників однієї культури - однорідним. Погодившись з тим, що і в першому, і в другому випадку це поле представлено символами і образами, з якими неминуче співвідносять себе суб'єкти комунікацій, ми, тим не менш, 
виявили специфіку поля міжкультурних комунікацій, визначивши його як мультикультурний простір, що $\epsilon$ сферою діалогічного співіснування представників різних культур, актуалізації їх повсякденного буття й вироблення єдиного нормативного поля. У зв'язку з цим ми вказуємо на істотну відмінність між соціокультурним простором, часом й мультикультурним простором. Це простір, що визначає динаміку міжкультурних комунікацій, характерний відсутністю єдності, сформовано цілісного, з наявністю як мінімум двох культур, двох єдностей і двох цілісностей, що й відрізняє його від простору соціокультурного.

Мультикультурний простір $є$ сферою буття «тут і зараз» представників різних культур, що характеризується особистісною самореалізацією та реалізацією індивідуально та культурно обумовленого повсякденного буття кожного 3 учасників міжкультурного діалогу. Існування комунікації в мультикультурному просторі відбувається в ситуації нестійкості, що має на меті нерелевантні культурні феномени, часто випадковий обмін символами, значеннями, смислами, трансформацію особистості й трансформацію знайомих соціокультурних стандартів, що в своїй сукупності й характеризує міжкультурні комунікації.

\section{References:}

1. Belle, T., Ward, C. (1996). Ethnic studies and multiculturalism. New York: State University of New York press.

2. Dibrova, V. (2019). 'Linguistic and speech means of expressing negation in english and ukrainian official and business discourse'. Mizhnarodni vidnosyny: teoretyko-praktychni aspekty [International relations: Theory and Practical Aspects], issue 3, pp. 226-233. DOI: 10.31866/2616-745x.3.2019.159125.

3. Giles, J., Middleton, T. (1999). Studying culture: a practical introduction. Maiden: Blackwell Publishers.

4. Haller, M. (2002). 'Theory and method in the comparative study of values. Critique and alternative to Inglehart'. European sociological review, vol. 18, issue 2, pp. 139-158.

5. Likarchuk, D. (2014). 'Osoblyvosti konfliktiv u politychnij sferi' [Features of the conflict in the political sphere]. Hileia, issue 83, pp. 358-361.

6. Steinmetz, H. (2001). 'Identität, Kultur (Literatur'). Globalisierung, Jahrbuch Deutsch als Fremdsprache (Intercultural German Studies), issue 27, pp. 105-127.

7. Waidenfels, B. (2000). 'Zwischen den Kulturen'. Globalisierung, Jahrbuch Deutsch als Fremdsprache (Intercultural German Studies), issue 26, pp.245-263.

(C) Діброва В. А., Лікарчук Д. С., 2019 